\title{
Green Building Guidelines at South African Universities
}

\author{
M. Struwig, G. Smit, and J. Van Wyk
}

\begin{abstract}
This paper presents a critical analysis of literature on green building guidelines at South African universities. The literature analysis resulted in the development of seventeen green building guidelines. The websites of all South African universities and the South African government were further content analyzed to investigate what they are doing regarding green buildings. Only three universities reported that they have a green building and only eight universities indicated a green activity on their websites. The government on the other hand had a rated green building and was extensively involved in the green economy. The four activities included in the websites were green research, green initiatives, green buildings, and future green plans. The results showed the need to develop green building guidelines for South African universities.
\end{abstract}

Index Terms-Green buildings, green building guidelines, green rating systems, content analysis.

\section{INTRODUCTION}

The first green building rating system called Building Research Establishment Environmental Assessment Method (BREEAM) was introduced in the United Kingdom in 1990. Since then there has been a rapid growth in the number of green building rating systems in the world, and in the span of 17 years more than 23 countries have adopted some kind of green building rating system. These rating systems are effectively guidelines for sustainable (green) buildings. Although the Green Building Council of South Africa has developed rating systems to evaluate a new building's energy and resource efficiency along with its environmental responsibility (Green Star), no rating system exists in South Africa with respect to the operation and maintenance of existing buildings. The United States Green Building Council's LEED (Leadership in Energy and Environmental Design) rating tool for existing buildings may be used in order to attain green building status through the operation and maintenance of an existing building.

Green building guidelines, as presently available at South African universities and the South African government will be explored by means of a content analysis of the websites. The intention is to ascertain which green building guidelines are reported on the websites. These results may add to a

Manuscript received June 10, 2013; revised July 16, 2013. This work was supported in part by the Nelson Mandela Metropolitan University Research Development fund.

M. Struwig is with School of Management Sciences, Nelson Mandela Metropolitan University, Port Elizabeth, 6031 South Africa (e-mail: Miemie.Struwig@nmmu.ac.za).

G. Smit is with Infrastructure and Projects, Nelson Mandela Metropolitan University, Port Elizabeth, 6031, South Africa (e-mail: Gerrit.Smit@nmmu.ac.za).

J. J. Van Wyk is with Human Settlements Development and Management, Nelson Mandela Metropolitan University, Port Elizabeth, 6031, South Africa (e-mail: KobusVanWyk@nmmu.ac.za). framework of green building guidelines that will be developed by critically analyzing literature.

TABLE I: KEY ISSUES INCLUDED IN THE GUIDELINES FOR GREEN BUILDINGS \begin{tabular}{|l|c|}
\hline IN AN INTERNATIONAL CONTEXT \\
\hline Roper and Beard [1] & KEY ISSUES \\
\hline & $\begin{array}{c}\text { Resource efficiency, such as sharing of } \\
\text { resources } \\
\text { Energy efficiency, including greenhouse }\end{array}$
\end{tabular}

- Energy efficien
gas emissions

- Pollution prevention, including indoor air quality and noise abatement

- Harmonization with the environment, including environmental assessments

- Integrated and systematic approaches, including environmental management systems

- Environmental site planning

- Energy-efficient building design

- Water conservation

- Carbon dioxide emission reduction

- Use of recycled and locally sourced materials

- Healthy buildings

\begin{tabular}{|ll}
\hline Lam, Chan, Chau, and & $\bullet$ Process of extraction or manufacture
\end{tabular}

Poon [3]

- Transport distance

- Procedures of application to minimize pollution during construction

- Energy protection

- Recycled materials use

- Indoor and outdoor air quality

- Applicable published standards for materials

- Additional acceptance tests on completion of work for verifying green effects

- Waste management plan for surplus/residue

\begin{tabular}{|c|c|}
\hline & \\
\hline $\begin{array}{l}\text { Atherton and Giurco } \\
\text { [4] }\end{array}$ & $\begin{array}{l}\text { - Climate change: to reduce emissions } \\
\text { - Transport: double the proportion of } \\
\text { staff/student commuting trips by } \\
\text { walking and cycling } \\
\text { - Paper reduction: decrease paper } \\
\text { purchased and increase recycled paper } \\
\text { use }\end{array}$ \\
\hline $\begin{array}{l}\text { LEED Rating System } \\
\text { [5] }\end{array}$ & $\begin{array}{l}\text { - } \text { Site and transportation issues } \\
\text { - } \text { Building envelopes } \\
\text { - } \text { Energy systems } \\
\text { - } \text { Inater and wastewater systems } \\
\text { - } \text { Waste systems } \\
\text { - Materials selection } \\
\text { - } \\
\text { Alteration/demolition }\end{array}$ \\
\hline Lui, Low, and $\mathrm{He}[6]$ & $\begin{array}{ll}\text { - } & \text { Sustainable sites } \\
\text { - } & \text { Reduction of building materials } \\
\text { - } & \text { Environmentally friendly materials } \\
\text { - } & \text { Water reduction and recycling } \\
\text { - } & \text { Indoor environmental quality } \\
\text { - } & \text { Luminance and ventilation } \\
\text { - } & \text { Sustainable operation } \\
\text { - } & \text { New green devices } \\
\text { - } & \text { Innovation in design } \\
\text { - } & \text { Reduction of effects on neighborhood } \\
\text { - } & \text { Cost of the green building }\end{array}$ \\
\hline
\end{tabular}

Source: Researcher's own compilation 


\section{LITERATURE OVERVIEW}

A number of guidelines and rating systems for green buildings exist in international contexts. Table I outlines key issues to be included in the green building guidelines of buildings in an international context.

From Table I, it is evident that there is general agreement on the key issues included in the guidelines for green buildings in the international context. Green building rating systems also exist that set standards for green buildings and are an objective assessment to determine how green a building is. Green building rating systems normally provide green measurements to be incorporated into a building to make it green.

A critical analysis of existing cases of green building guidelines in Hong Kong by Lam,Chan, Chau, and Poon [3]; in India by Potbhare [7]; in North America by WBGC [8]; in China by Tan [9], and in Australia by the Green Building Council Australia [10], show a comparison of these international green building guidelines. Table II shows a comparison of the international green building guidelines.

TABLE II: A COMPARISON OF THE INTERNATIONAL GREEN BUILDING GUIDELINES

\begin{tabular}{|c|c|c|c|c|c|}
\hline CRITERIA & $\begin{array}{l}\bar{T} \\
O \\
Z \\
\Omega \\
\overparen{O} \\
0 \\
Z \\
\Omega\end{array}$ & $\underset{\nabla}{Z}$ & 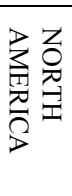 & $\underset{D}{\stackrel{Z}{Z}}$ & 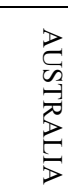 \\
\hline Workmanship & $\mathrm{x}$ & & & & $\mathrm{X}$ \\
\hline $\begin{array}{l}\text { Procedures to minimize pollution } \\
\text { during construction }\end{array}$ & $\mathrm{x}$ & & $\mathrm{x}$ & $\mathrm{x}$ & $\mathrm{X}$ \\
\hline $\begin{array}{l}\text { Protection measures for } \\
\text { vulnerable parties/structures }\end{array}$ & $\mathrm{x}$ & $\mathrm{x}$ & $\mathrm{x}$ & & $\mathrm{X}$ \\
\hline Recycling practice/instructions & $\mathrm{x}$ & & $\mathrm{x}$ & & $\mathrm{x}$ \\
\hline Indoor and outdoor air quality & $\mathrm{x}$ & $\mathrm{x}$ & $\mathrm{x}$ & & $\mathrm{x}$ \\
\hline $\begin{array}{l}\text { Applicable published code of } \\
\text { practice }\end{array}$ & $\mathrm{x}$ & & $\mathrm{x}$ & $\mathrm{x}$ & $\mathrm{x}$ \\
\hline $\begin{array}{l}\text { Additional acceptance tests on } \\
\text { completion of work to verify } \\
\text { green effects }\end{array}$ & $\mathrm{x}$ & & $\mathrm{x}$ & $\mathrm{x}$ & $\mathrm{x}$ \\
\hline $\begin{array}{l}\text { Instructions for maintenance and } \\
\text { operation }\end{array}$ & $\mathrm{x}$ & & $\mathrm{x}$ & & $\mathrm{x}$ \\
\hline Sustainable site & & $\mathrm{x}$ & $\mathrm{x}$ & & $\mathrm{x}$ \\
\hline Water efficiency & $\mathrm{x}$ & $\mathrm{x}$ & $\mathrm{x}$ & & $\mathrm{x}$ \\
\hline Energy \& atmosphere & & $\mathrm{x}$ & $\mathrm{x}$ & & $\mathrm{x}$ \\
\hline Material \& resources & & $\mathrm{x}$ & $\mathrm{x}$ & & $\mathrm{x}$ \\
\hline Innovation design & & $\mathrm{x}$ & $\mathrm{x}$ & & $\mathrm{x}$ \\
\hline Regional priority & & $\mathrm{x}$ & & & $\mathrm{x}$ \\
\hline
\end{tabular}

Source: Researchers' own compilation

Table II indicates that none of the criteria are applied in all the countries. However, criteria such as procedures to minimize pollution during construction, protection measures for vulnerable parties/structure, indoor and outdoor air quality, applicable published code of practice, additional acceptance tests on completion of work to verify green effects and water efficiency are applied by four of the five countries and are thus seen to be important in the international context. In the next paragraphs green building guidelines in the South African context will be discussed.

Research into green guidelines for buildings in South African context is scanty. In this overview only two specific cases are considered, namely, the City of Cape Town and the University of Cape Town, which can be regarded as the leaders in South Africa.

\section{A. City of Cape Town Green Building Guidelines}

The City of Cape Town [11] has provided some principles to serve as green building guidelines, namely, that green buildings should:

- Complement the social, economic and cultural context within which they are situated and thus be locally appropriate;

- Follow an environmentally sensitive approach to the design and construction of the built environment, and an approach which aims to conserve the natural resources and ecosystems;

- Promote resource efficiency in all aspects of planning, construction, operation, and maintenance of buildings, such as energy- and water-efficient technologies, management systems and behavior;

- Ensure that decisions about the design of a building and the specification of the materials from which it is made take the entire lifecycle of these products into consideration, so as to select the best overall options;

- Aim to achieve zero waste in the construction and operation of the built environment;

- Promote the use of renewable energies in the manufacturing of building products and in generating the energy used in green buildings;

- Ensure that goods and services procured in the planning, operation, management and maintenance of green buildings are sustainable;

- Ensure that products and materials are sourced and manufactured in the vicinity of a development, to reduce energy in transporting materials from long distances to the site;

- Ensure that primary goals in designing and constructing the built environment are to develop healthy environments in which people can live, work and play;

- Gather information on the impact of green building interventions to raise awareness and share learning;

- Ensure that both the short- and long-term impact of decisions and actions of managers lead to sustainability.

The above guidelines can serve as possible indicators to a framework for establishing guidelines to green buildings.

\section{B. Green Building Guidelines Developed by the University of Cape Town}

The University of Cape Town's Green Campus Initiative is based on the example of Harvard University's Green Campus Initiative [12]. The Harvard initiative is based on a business model where an independent unit worked on targeted projects and programs across research, teaching, and administration.

The Green Campus Plan at the University of Cape Town includes a status quo document that shows the existing situation at the university, a plan of action on what should be done, and a policy statement indicating the institution's key objectives and aims.

The responsibility for the overall management and monitoring of a Green Campus Plan will rest with Properties and Services. However, the success of the plan will depend 
on its adoption across all sectors of the university. To be successful, it is recommended that the University Building and Development Committee, Senate and Council:

- Formally adopt a policy framework;

- Adopt specific milestones and delivery targets for the areas identified by the appropriate agencies within the university;

- Draw up policies for partnerships and the appointment of outside operators where deemed necessary, including consultants and contractors for specific project-directed tasks;

- Introduce an awareness and communication strategy, including web and online information;

- Encourage faculties as well as administrative and support departments to adopt practices which contribute to the objectives of the policy framework, with appropriate recognition of the implementation of good practices; and

- $\quad$ Regard this framework as an initial stage in widening the concept of sustainability to embrace the core work of the university.

An analysis of the guidelines suggests that the following guidelines (as a minimum) should be included when developing a sustainable green building:

- $\quad$ Project commitment;

- $\quad$ Project communication;

- Relevant partnerships; and

- Campus community engagement.

In critically analyzing the green building guidelines in the international context and looking at the South African context, seventeen aspects emerged that need to be considered when developing green building guidelines. Table III provides a summary of the aspects to consider in the development of green building guidelines.

TABLE III: ASPECTS TO CONSIDER FOR DEVELOPING GREEN BUILDING GUIDELINES AT SOUTH AFRICAN UNIVERSITITES

\begin{tabular}{|l|}
\hline Aspects to consider in the development of green building guidelines. \\
\hline Sustainable/durable/low maintenance building design and operation \\
\hline Energy efficiency and conservation \\
\hline Site/Land management, renovation and conservation \\
\hline Water efficiency \\
\hline Indoor air quality \\
\hline Outdoor air quality \\
\hline Material resource management and recycling \\
\hline Rating systems \\
\hline Building envelope \\
\hline Project commitment \\
\hline Project communication \\
\hline Relevant partnerships \\
\hline Campus community engagement \\
\hline Retrofitting - greening existing buildings \\
\hline Carbon neutrality \\
\hline Green or living roofs \\
\hline Waste \\
\hline Source: Researchers' own compilation \\
\hline
\end{tabular}

The aspects to consider in the development of green building guidelines as shown in Table III set the scene for developing a set of green building guidelines that can be implemented at university campuses in South Africa. Green building guidelines, as currently available at South African universities, were explored by means of a content analysis of the websites of all South African universities. The intention was to determine which green building guidelines were reported on the websites. The methodology followed to investigate the websites of South African universities was qualitative in nature.

\section{RESEARCH DESIGN}

All the websites of South African universities were investigated to find any information on them regarding green project, building, or other initiatives of the university and/or any green building guidelines. During May 2012, the websites of all 23 universities in South Africa were researched.

TABLE IV: SAMPLE OF SOUTH AFRICAN UNIVERSITY AND SOUTH AFRICAN GOVERMENT WEBSITES AND GREEN INITIATIVES

\begin{tabular}{|c|c|c|}
\hline UNIVERSITIES & WEB ADDRESS & GREEN \\
\hline University of Limpopo & www.ul.ac.za & NO \\
\hline Rhodes University & www.ru.ac.za & YES \\
\hline $\begin{array}{l}\text { University of Cape Town, } \\
\text { Uct }\end{array}$ & www.uct.ac.za & YES \\
\hline $\begin{array}{l}\text { Cape Peninsula University } \\
\text { of Technology }\end{array}$ & www.cput.ac.za & YES \\
\hline North West University & www.nwu.ac.za & YES \\
\hline $\begin{array}{l}\text { Central University of } \\
\text { Technology }\end{array}$ & www.cut.ac.za & NO \\
\hline $\begin{array}{l}\text { Mangasuthu University of } \\
\text { Technology }\end{array}$ & www.mut.ac.za & $\mathrm{NO}$ \\
\hline Walter Sisulu University & www.wsu.ac.za & $\mathrm{NO}$ \\
\hline University of the Free State & www.ufs.ac.za & $\mathrm{NO}$ \\
\hline $\begin{array}{l}\text { Durban University of } \\
\text { Technology }\end{array}$ & www.dut.ac.za & NO \\
\hline $\begin{array}{l}\text { University of Kwazulu } \\
\text { Natal }\end{array}$ & www.ukzn.ac.za & NO \\
\hline $\begin{array}{l}\text { Nelson Mandela } \\
\text { Metropolitan University }\end{array}$ & www.nmmu.ac.za & YES \\
\hline University of Stellenbosch & www.sun.ac.za & $\mathrm{NO}$ \\
\hline $\begin{array}{l}\text { Tshwane University of } \\
\text { Technology }\end{array}$ & www.tut.ac.za & YES \\
\hline $\begin{array}{l}\text { University of } \\
\text { Johannesburg }\end{array}$ & www.uj.ac.za & $\mathrm{NO}$ \\
\hline University of Fort Hare & www.ufh.ac.za & NO \\
\hline Unisa & www.unisa.ac.za & YES \\
\hline University of Pretoria & www.up.ac.za & YES \\
\hline University of Venda & www.univen.ac.za & $\mathrm{NO}$ \\
\hline $\begin{array}{l}\text { Vaal University of } \\
\text { Technology }\end{array}$ & www.vut.ac.za & $\mathrm{NO}$ \\
\hline $\begin{array}{l}\text { University of The Western } \\
\text { Cape }\end{array}$ & www.uwc.ac.za & NO \\
\hline University of Zululand & www.unizulu.ac.za & NO \\
\hline South African Government & www.gov.za & YES \\
\hline
\end{tabular}

\section{A. The Sample, Respondents and Data Collection}

During May 2012, the websites of all 23 universities in South Africa were investigated. Any information found on green initiatives was downloaded and saved in a file for the specific university. Of the 23 universities only 8 of their websites provided any information about green initiatives. 
During July 2013 it was decided to also include the website of the Government of South Africa to this study to investigate whether it does not provide specific pointers for universities to include in their green building guidelines.

Table IV outlines the results of the websites investigated and those that reported green initiatives on their website.

Table IV show that only eight universities and the South African government reported any green initiative on their websites.

\section{B. Procedure of Content Analysis of the Websites}

The eight files downloaded from the universities and the South African Government that reported green initiatives, were collated and printed. The following process was used to content-analyze the printed information.

- Downloading and printing a copy of the selected website. Relevant information was marked while reading through the information and brief notes were made in the margins about the nature of the information.

- Identifying information by studying the margin notes.

- Categorizing the list of items extracted from the text so that the green initiative focus was described. At this stage, as many categories as possible were identified, since the number of categories could be reduced at a later stage if necessary.

- Considering the list of categories identified from the transcript (information from websites). It was determined whether any of the categories were linked in some way (categories and sub-categories).

- Establishing a final list of categories. The list was finalised when no new categories emerged, and all information had been accommodated in the existing categories. At this stage, the different categories were colour-coded with a highlighter pen for each category, to emphasize items of data in the transcripts (information from websites).

- $\quad$ Ensuring that information that was not highlighted at all (because it did not appear relevant at the time) was checked once again for relevance.

- Triangulating the finalized categories with another researcher to see if she/he identified the same categories and agreed with the list produced.

Trustworthiness of the research was enhanced by involving more than one researcher to analyze the data, as recommended by Struwig and Stead [13]. Inter-rater reliability was also achieved in that another researcher verified the categories and ensured that the data was correctly analyzed. The researcher who verified the categories was an experienced researcher in the field of management sciences and had used content analysis as a methodology before. As the information was obtained from public websites and was part of the public domain, no ethical clearance was needed.

\section{Results of the Content Analysis}

By using the procedure explained, various categories of green initiatives reported on the website were identified. This identification of green initiatives did not focus only on green building guidelines, but on all green initiatives reported.

By analyzing the content, the following four categories emerged:

\section{- Green Research}

This category included reporting on research of staff members on sustainability. It described research in the form of a complete published article by a staff member, to those who had only indicated that the research area of sustainability was important at their university.

\section{- Green Building}

This category indicated whether the website reports any green buildings or any guidelines for green buildings.

\section{- Green Initiatives}

This category included green initiatives by either staff or students at the university or initiatives by government.

\section{- $\quad$ Future Plans}

Many universities reported on their websites about what they were still planning to do in the future with respect to becoming green. This was included in this category. The government also reported on future plans in this domain.

The refinement of the content analysis resulted in the following:

\section{a) Tshwane University of Technology}

The information published on their website related to:

- Research on sustainable built environments

- Construction of green buildings - the Architecture Department planned for the future

\section{b) Rhodes University}

On the website the following were found:

- Research into forming an environmental committee

- Green initiatives to involve community and students

- Future plans to establish a green fund, to save energy, recycling, re-use water, environmental awareness and establish vegetable gardens for the residences

\section{c) Cape Peninsula University of Technology}

The only information found on the website related to:

- Green initiatives on green team students' eco-friendly business plans, and a green radio on campus

\section{d) Nelson Mandela Metropolitan University}

Information on the Nelson Mandela Metropolitan University included

- Research, vision, and mission statement - part of our values

- Green initiatives on the George campus

e) North West University

On the website the following information was reported:

- Research in the form of an article published by an academic staff member

- Future plans for a new green building - a new campus library is still to be built

\section{f) University of Pretoria}

The following information was provided on the website:

- Research - produced a research paper on green IT strategy

- $\quad$ Green buildings - School of Engineering

- $\quad$ Future plans - new Plant Science building

g) UNISA

The following information was found on the website: 
- Research on sustainable reporting

- Green initiatives of students and lecturers

\section{h) University of Cape Town}

The website of the university showed the following:

- $\quad$ Research including a policy framework, the UCT vision of a shift towards becoming more green, and students winning an award for developing green building management software

- Green buildings included an Engineering building with Green Star rating

- Green initiatives such as a green campus unit who were responsible for driving the green project and many student initiatives

\section{i) The South African Government}

The following information was found on the website of the South African Government:

- Department of Environmental Affairs has a green building that received a six star Green Star SA Office Design Certification by the Green Building Council of South Africa

- Consultative sessions on Built Industry contribution to the South African green economy

- Green building exhibitions

- Best practices for green building certification

- Green building project by Environmental Affairs

- $\quad$ Public works green building programme

Table $\mathrm{V}$ provides a summary of the aspects found on the various websites.

TABLE V: GREEN-RELATED CONTENT FOUND ON SOUTH AFRICAN UNIVERSITY WEBSITES

\begin{tabular}{|c|c|c|c|c|}
\hline \multirow[b]{2}{*}{ University } & \multicolumn{4}{|c|}{ Green Initiative Reported On Website } \\
\hline & Research & $\begin{array}{c}\text { green } \\
\text { buildings }\end{array}$ & $\begin{array}{l}\text { Green } \\
\text { initiatives } \\
\end{array}$ & $\begin{array}{l}\text { Future } \\
\text { plans }\end{array}$ \\
\hline $\begin{array}{l}\text { Cape Peninsula } \\
\text { University of } \\
\text { Technology }\end{array}$ & & & $\mathrm{X}$ & \\
\hline $\begin{array}{l}\text { Cape Town } \\
\text { University }\end{array}$ & $\mathrm{X}$ & $\mathrm{X}$ & $\mathrm{X}$ & \\
\hline $\begin{array}{l}\text { Nelson Mandela } \\
\text { Metropolitan } \\
\text { University }\end{array}$ & $\mathrm{X}$ & & $\mathrm{X}$ & \\
\hline $\begin{array}{l}\text { North West } \\
\text { University }\end{array}$ & $\mathrm{X}$ & & & $\mathrm{X}$ \\
\hline Pretoria University & $\mathrm{X}$ & $\mathrm{X}$ & & $\mathrm{X}$ \\
\hline Rhodes University & & & $\mathrm{X}$ & $\mathrm{X}$ \\
\hline $\begin{array}{l}\text { Tshwane University } \\
\text { of Technology }\end{array}$ & $\mathrm{X}$ & & & \\
\hline UNISA & $\mathrm{X}$ & & $\mathrm{X}$ & \\
\hline $\begin{array}{l}\text { South African } \\
\text { Government }\end{array}$ & $\mathrm{X}$ & $\mathrm{X}$ & $\mathrm{X}$ & $\mathrm{X}$ \\
\hline TOTAL & 7 & 3 & 6 & 4 \\
\hline
\end{tabular}

Source: Researchers' own compilation from content analysis

In Table $\mathrm{V}$ it is shown that information available on South African university websites regarding green buildings is scanty, and only two universities, namely the University of Cape Town and the University of Pretoria, reported that they had a green building. The South African Government on the other hand indicated that they not only have a green building, but that it complies with a six star Green Star SA Office Design from the Green Building Council of South Africa.

None of the universities posted guidelines for green buildings on their websites, therefore it could not be ascertained whether they had such guidelines and how they compared with the rating systems found in the literature. The Government on the other hand pointed out that the green requirements in buildings involve three factors, namely the environmental impact, the response to social well-being and response to improved economic performance.

This exploratory analysis of websites in South Africa did not produce any specific green building guidelines to add to the seventeen green building aspects identified in literature, but the results showed that there is a great need to develop such guidelines, and that the South African university sector is indeed faced with a great challenge in this area. When compared to the South African government, the university sector lags behind. The South African Government has taken leadership in green building and provides an outstanding example of public private sector partnerships.

\section{CONCLUSION}

The research indicated that a far better response from universities is needed to provide sustainable and green buildings on university campuses. As the next generation of leaders is currently attending lectures in classrooms, visiting the university libraries as well as living and dining in spaces of South African Higher Education Institutions, the question can be posed whether the buildings are compromising students' ability to learn, or whether they enhance their learning experiences. As conventional education buildings are typically designed to meet only minimum standards as stipulated in building codes, the result is that facilities are not necessarily designed to provide comfortable, productive or healthy work environments for students. Although the Green Building Council of South Africa has developed rating systems to evaluate a new building's energy and resource efficiency along with its environmental responsibility (Green Star), there is still uncertainty whether South African universities use these rating systems and implement the principles required to develop green buildings. The results of the content analysis set the scene for empirically testing the seventeen proposed aspects to consider when developing guidelines for green buildings at South African universities. Universities can also benefit by following the South African Government's lead in green buildings. As the Built Environment has the potential to undermine the environment severely, the construction sector is therefore a key sector to mitigate these negative effects.

\section{REFERENCES}

[1] K. O. Roper and J. L. Beard, "Justifying sustainable buildings-championing green operations," Journal of Corporate Real Estate, vol. 8, no. 2, pp. 91-103, 2006.

[2] J. Yudelson, Green Building A to Z. Understanding the language of Green Building, Canada: New Society Publishers, 2007.

[3] T. I. Lam, E. H. W. Chan, C. K. Chau, and C.S. Poon, "A sustainable framework of "green" specification for construction in Hong Kong," Journal of Facilities Management, vol. 9, no. 1, pp. 16-33, 2011.

[4] A. Atherton and D. Giurco, "Campus sustainability: climate change, transport and paper reduction," International Journal of Sustainability in Higher Education, vol. 12, no. 3, pp. 269-279, 2011.

[5] LEED Rating System. (January 2012). [Online]. Available: www.usgbc.org. 
[6] J. Y. Lui, S. P. Low, and X. He, Green practices in the Chinese Building Industry: Drivers and Impediments, Emerald preprint, 2012.

[7] V. Potbhare, "Adoption of green building guidelines in the developing countries based on US and India experiences," Construction Management Program, Research report, Michigan State University, East Lansing, MI, 2008.

[8] WBGC, (May 2008). US Green Building Council. Green building research. [Online]. Available: http://www.usgbc.org.

[9] J.X. Tan, "LEED certification in China," CIOB-Contact China, no. 9, pp. 19-20, 2010

[10] Green Building Council of Australia. (May 2012). [Online]. Available: http:// www.gbca.org.au/.

[11] City of Cape Town, City of Cape Town Green Building Guidelines, Cape Town: Environmental Resource Management, 2008.

[12] Energy Management, "A green campus policy framework for the University of Cape Town," Energy Management News, vol. 14, no. 3, pp. 1-4, 2008.

[13] F. W. Struwig and G.B. Stead, Planning, designing and reporting research, Cape Town: Pearson Education, 2001.

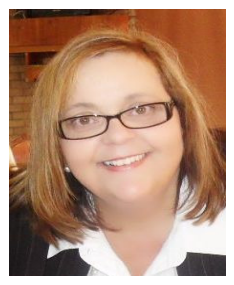

Miemie Struwig is currently the director of the School of Management Sciences at the Nelson Mandela Metropolitan University in Port Elizabeth South Africa. She obtained her PhD degree in 1991 after completing a Masters in Commerce at the University of Port Elizabeth, South Africa.

She is currently lecturing Business Research to post graduate students and supervise master and doctoral students. She has successfully supervised 31 master and doctoral students. She is currently a Journal reviewer for most South African accredited Journals in the field of Business and also two International Journals in Poland and Russia. She acts as external examiner for Masters' and Doctoral students at the following universities: Rhodes University, University of Stellenbosch, University of Johannesburg, Pretoria University, University of Kwa-Zulu Natal and University of the Orange Free State.
Professor Struwig is currently member of the South Africa Finance Association (SAFA) and the South African Institute for Management Scientists (SAIMS). Before returning to her academic school Miemie was campus principal at one the Nelson Mandela Metropolitan University campuses. She has published extensively in local and international journals and has delivered papers both nationally and internationally.

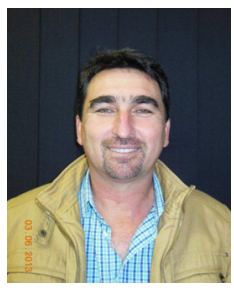

Gerrit Smit is currently the project manager at the Department of Infrastructure and Projects at the Nelson Mandela Metropolitan University, Port Elizabeth South Africa. He is currently busy with his Master degree in Construction Management. Mr Smit is currently registered as a Professional Construction Project Manager by the South African Council for Project and Construction Management Professions (SACPCMP).

Mr Smit has been employed in the construction industry for the past 21 years. During his studies he has delivered a paper at an international conference. He also worked overseas for 3 years in his field.

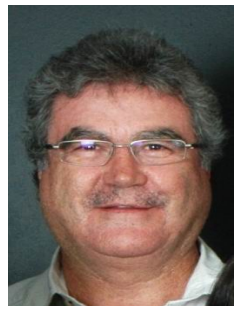

Van Wyk has various qualifications and is registered with two professional councils. He has a passion to contribute to development in a multi-disciplinary context, but specifically to human settlement development and management. To this end he does research and present formal and non-formal education programmes.

He has been in various academic positions, among other Dean of Faculty for thirteen years. At present he holds the DHS Chair for Education in Human Settlements Development and Management at the NMMU, which will start to offer the professional Bachelor's degree in Human Settlement Development from 2014. 